\title{
Analisis Pengukuran Kesuksesan Sistem Informasi
}

\author{
Imay Kurniawan, S.Si. \\ Dosen Program Studi Manajemen Informatika \\ Politeknik LP3I Bandung \\ Email : ce6920@gmail.com
}

\begin{abstract}
Abstrak : Sistem informasi yang didukung teknologi informasi dapat memberikan nilai tambah bagi organisasi jika didesain menjadi sistem informasi yang efektif, yang menandakan bahwa sistem informasi tersebut sukses. Namun demikian pengukuran kesuksesan sistem informasi sulit dilakukan secara langsung. Diperlukan identifikasi faktor-faktor penyebab kesuksesan sistem informasi, yang digunakan untuk mengembangkan suatu model kesuksesan sistem informasi. Untuk menguji model tersebut akan digunakan metode Struktural Equation Modeling(SEM).
\end{abstract}

Banyak penelitian telah dilakukan untuk mengidentifikasikan faktor-faktor yang menyebabkan kesuksesan sistem teknologi informasi. Salah satu penelitian yang terkenal di area ini adalah penelitian yang dilakukan oleh (DeLone \& McLean,1992). Model kesuksesan sistem teknologi informasi yang dikembangkan oleh DeLone \& McLean ini cepat mendapat tanggapan. Salah satu sebabnya adalah model mereka merupakan model yang sederhana tetapi dianggap cukup valid.

Model kesuksesan sistem informasi yang akan dikembangkan oleh penulis, adaptasi dari model Delone \& McLean yang dimodifikasi dengan menambah variabel kualitas layanan. Menurut (Pitt et al ,1995) apabila komponen kualitas layanan tidak diikut sertakan maka akan terdapat kesalahan dalam pengukuran kesuksesan sistem informasi.

Kata kunci : faktor-faktor kesuksesan sistem informasi, model kesuksesan sistem informasi,SEM

\section{Pendahuluan}

\section{Latar Belakang Masalah}

Pengembangan sistem informasi merupakan investasi yang mahal. Meskipun demikian, investasi yang mahal belum tentu mendapatkan sistem yang berkualitas dan sesuai dengan apa yang diharapkan oleh organisasi. Keberhasilan implementasi sistem dipengaruhi oleh berbagai faktor yang komplek. Sedangkan kegagalan implementasi sistem, biasanya terjadi karena tidak kompatibelnya sistem dengan proses bisnis dan informasi yang diperlukan organisasi.

Tata kelola teknologi informasi yang baik dapat terindikasi pada tingkat efektifitas sistem informasi. Efektifitas sistem didefinisikan sebagai kemampuan sistem informasi untuk melaksanakan fungsinya dalam mendukung tujuannya secara khusus dan tujuan organisasi secara umum. Pengukuran efektivitas sistem 
informasi dapat memperlihatkan gambaran sukses atau tidaknya pengembangan atau penerapan sistem tersebut. (Alfan dan Budiman,2013).

Namun demikian pengukuran kesuksesan sistem informasi sulit dilakukan secara langsung. Diperlukan identifikasi faktor-faktor penyebab kesuksesan sistem informasi, yang digunakan untuk mengembangkan suatu model kesuksesan sistem informasi. Struktural Equation Modeling(SEM) merupakan metode statistik yang tepat untuk menguji model kesuksesan sistem informasi.

Banyak penelitian telah dilakukan untuk mengidentifikasikan faktor-faktor yang menyebabkan kesuksesan sistem teknologi informasi. Salah satu penelitian yang terkenal di area ini adalah penelitian yang dilakukan Delone \& McLean (1992).

Model kesuksesan sistem teknologi informasi yang dikembangkan oleh DeLone \& McLean (1992) ini cepat mendapat tanggapan. Salah satu sebabnya adalah model mereka merupakan model yang sederhana tetapi valid.

\subsection{Rumusan Masalah}

1. Bagaimana membuat model pengembangan kesuksesan sistem informasi

2. Bagaimana membuat metodologi untuk menguji model kesuksesan sistem informasi

\subsection{Tujuan Penelitian}

1 .Mengetahui membuat model pengembangan kesuksesan sistem informasi

2. Mengetahui membuat metodologi menguji model kesuksesan sistem informasi

\section{Tinjauan Pustaka}

\subsection{Model Dasar Kesuksesan Sistem Informasi}

Banyak penelitian telah dilakukan untuk mengidentifikasikan faktor-faktor yang menyebabkan kesuksesan sistem informasi. Salah satu penelitian yang terkenal di area ini adalah yang dilakukan oleh (Delone and Mclean,1992). Model kesuksesan sistem informasi yang dikembangkan oleh (Delone and Mclean,1992) ini cepat mendapat tanggapan. Salah satu sebabnya adalah model mereka merupakan model yang sederhana tetapi dianggap cukup valid. Model yang

Model yang diusulkan ini merefleksi ketergantungan dari enam pengukuran pengukuran kesuksesan sistem informasi.

Keenam elemen atau faktor atau komponen atau pengukuran dari model ini adalah:

1. Kualitas sistem (system quality)

2. Kualitas informasi (information quality)

3. Penggunaan (use)

4. Kepuasan pengguna (user satisfaction)

5. Dampak individual (individual impact)

6. Dampak organisasi (organization impact) 


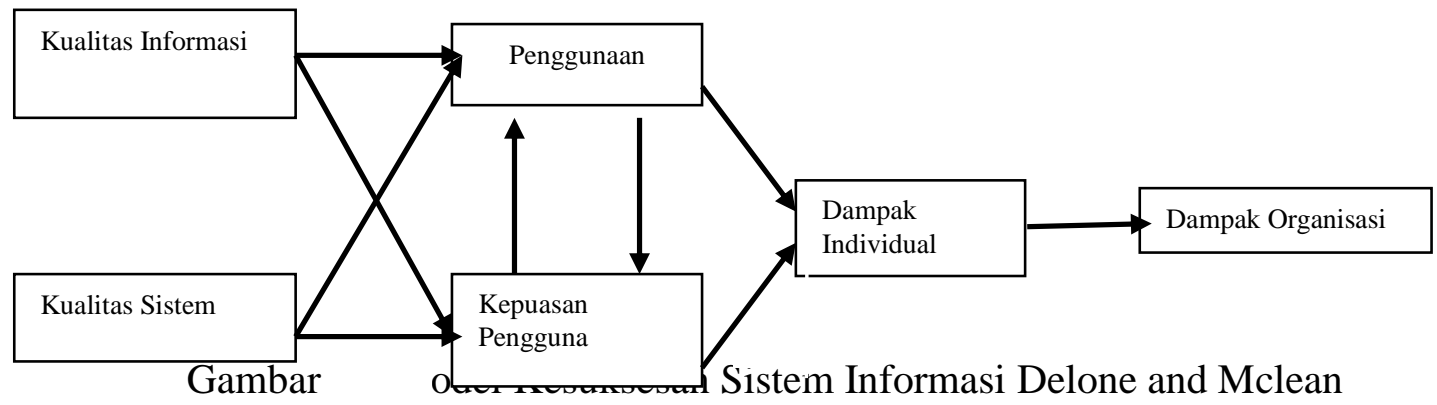

(Sumber : Delone and Mclean,1992)

Model kesuksesan ini didasarkan pada proses dan hubungan kausal dari dimensidimensi di model. Model ini tidak mengukur ke enam dimensi pengukuran kesuksesan sistem informasi secara independen tetapi mengukurnya secara keseluruhan satu mempengaruhi yang lainnya.

Pertimbangan proses berargumentasi bahwa suatu sistem terdiri dari beberapa proses, yaitu satu proses mengikuti proses yang lainnya. Suatu model proses mengusulkan bahwa suatu sistem informasi terdiri dari beberapa proses, yaitu sebagai berikut :

1. Suatu sistem informasi mula-mula dibuat berisi dengan banyak fitur, yang dapat memperlihatkan beberapa tingkat kualitas sistem dan kualitas informasinya.

2. Pengguna-pengguna dan manajer-manajer mempunyai pengalaman dengan fitur-fitur tersebut dengan menggunakan sistemnya, entah mereka puas atau tidak puas dengan sistemnya atau produk informasinya.

3. Penggunaan dari sistem dan produk informasinya kemudian mempunyai dampak atau pengaruh (influence) di pengguna individu di dalam melakukan pekerjaannya. Dampak-dampak individu ini secara kolektif akan berakibat pada dampak-dampak oraganisasi

Berbeda dengan model proses model kausal atau disebut juga dengan model varian (variance model) berusaha untuk menjelaskan kovarian (covariance) dari elemen-elemen model untuk menentukan apakah apakah varian dari satu elemen dapat dijelaskan oleh varian dari elemen-elemen lainnya atau dengan kata lain untuk menentukan apakah terjadi hubungan kausal diantara mereka. Misalnya, semakin tinggi kualitas sistem diharapkan akan menyebabkan kepuasan pengguna dan penggunaan yang lebih tinggi, yang selanjutnya akan mempengaruhi secara positip produktivitas organisasi. Model kausal ini menunjukkan bagaimana arah hubungan satu elemen dengan elemen lain apakah menyebabkan lebih besar (mempunyai pengaruh positif) atau lebih kecil (mempunyai pengaruh negatif).

Dari model proses dan kausal ini, maka dapat dijelaskan bahwa kualitas sistem (system quality) dan kualitas informasi (information quality) secara mandiri dan bersama sama mempengaruhi baik penggunaan (use) dan kepuasan pengguna 
(user satisfaction). Besarnya penggunaan (use) dapat mempengaruhi kepuasan pengguna (user satisfaction) secara positif atau negatif. Penggunaan (use) dan kepuasan pengguna (user satisfaction) mempengaruhi dampak individu (individual impact) dan selanjutnya mempengaruhi dampak organisasi(organizational impact).

Pada perkembangannya terdapat penelitian - penelitian lain yang membuktikan maupun menawarkan pengembangan model kesuksesan sistem informasi tersebut, antara lain Seddon yang melakukan perubahan model Delone \& McLean menjadi dua varians model yang terpisah (Seddon, 1997). Dalam model barunya Seddon menggantikan variabel use dengan perceived usefulness. Selain itu Seddon juga menambahkan variabel societal impact. Penelitian lainnya yaitu oleh (Pitt et al ,1995) yang menambahkan komponen kualitas layanan. Apabila komponen kualitas layanan tidak diikut sertakan, maka akan terdapat kesalahan dalam pengukuran efektifitas sistem informasi tersebut.

Menurut (Pitt et al ,1995) menyatakan bahwa ukuran-ukuran efektifitas sistem informasi lebih fokus pada produk daripada layanan yang diberikan oleh fungsi sistem informasi, sehingga akan membahayakan bagi para peneliti karena dapat mengukur efektifitas sistem secara salah sebagai akibat tidak dimasukkannya ukuran service quality kedalam paket penilaian mereka. Instrumen pengukuran yang digunakan adalah servqual yang dikemukakan oleh (Parasuraman et al,1985), yang disusun untuk mengakses harapan konsumen dan persepsi mengenai kualitas pelayanan dalam organisasi retail dan jasa

\subsection{Faktor-Faktor Yang Mempengaruhi Kesuksesan Sistem Informasi}

\subsubsection{Kualitas Sistem}

Menurut (Jogiyanto,2007), kualitas sistem digunakan untuk mengukur kualitas sistem teknologi itu sendiri. Pendapat lain yang mengungkapkan definisi yang sama adalah (Chen,2010).

Kualitas sistem merupakan suatu ukuran pengolahan sistem informasi itu sendiri. (Nelson et al,2005) menjelaskan kualitas sistem dapat diukur melalui lima dimensi antara lain:

1. Reliabilitas, mengukur keandalan atas sistem yang dioperasikan.

2. Fleksibilitas, sistem dapat menyesuaikan dengan berbagai kebutuhan pengguna dan ke kondisi yang berubah-ubah.

3. Integrasi, sistem memudahkan dalam menggabungkan data dari berbagai macam sumber untuk mendukung pengambilan keputusan bisnis.

4. Aksesibilitas, kemudahan untuk mengakses informasi ataupun kemudahan untuk menghasilkan informasi dari suatu sistem.

5. Waktu respon, mengasumsikan respon sistem yang cepat atau tepat waktu terhadap permintaan akan informasi. 


\subsubsection{Kualitas Informasi}

Menurut Jogiyanto (2007) mengemukakan bahwa "Kualitas informasi mengukur kualitas keluaran dari sistem informasi". (Ong et al,2009) berpendapat bahwa "Kualitas informasi dapat diartikan pengukuran kualitas konten dari sistem informasi". (Negash et al,2003) menjelaskan "Kualitas informasi adalah suatu fungsi yang menyangkut nilai dari keluaran informasi yang dihasilkan oleh sistem". (Jogiyanto,2007) menjelaskan bahwa kualitas informasi dapat diukur oleh tiga indikator:

1. Akurat, informasi harus bebas dari kesalahan-kesalahan dan tidak bias atau menyesatkan. Informasi harus memiliki keakuratan tertentu agar tidak diragukan kebenarannya.

2. Tepat pada waktunya, informasi yang datang pada penerima tidak boleh datang terlambat, karena informasi yang datang tidak tepat waktu, tidak bernilai lagi, sebab informasi digunakan dalam proses pembuatan keputusan.

3. Relevan, informasi yang ada memiliki nilai kemanfaatan sesuai dengan yang dibutuhkan oleh pemakainya. Informasi emmiliki tingkat relativitas yang berbeda, tergantung pada tingkat pemakai.

\subsubsection{Kualitas Layanan ( service quality)}

Kualitas layanan merupakan perbandingan antara layanan yang dirasakan (persepsi) konsumen dengan kualitas layanan yang diharapkan konsumen. Jika kualitas layanan yang dirasakan sama atau melebihi kualitas layanan yang diharapkan, maka layanan dikatakan berkualitas dan memuaskan (Kotler,2003).

Menurut (Parasuraman,1985), menjelaskan kualitas layanan dapat diukur melalui tiga indikator antara lain:

1. Reliability (kehandalan), kemampuan sistem informasi memberikan layanan yang akurat tanpa membuat kesalahan.

2. Responsiveness (ketanggapan/kepedulian), Sistem informasi memberikan layanan secara cepat.

3. Assurance (jaminan kepastian), Sistem informasi membuat pengguna merasa aman sewaktu melakukan transaksi

\subsubsection{Penggunaan (use)}

Dalam model kesuksesan (DeLone andMcLean,1992) diasumsikan bahwa kualitas sistem dan kualitas informasi yang dihasilkan dapat mempengaruhi penggunaan sistem informasi. Jika kualitas sistem dan kualitas informasi yang dihasilkan sistem semakin baik maka kepuasan pengguna akan cenderung meningkat sehingga intensitas penggunaan sistem informasi juga akan semakin meningkat.

Penggunaan sistem dapat diukur melalui tiga indikator antara lain:

1. Motivasi untuk menggunakan sistem (De Sanctis, 1982) 
2. Frekuensi penggunaan sistem (DeLone andMcLean,1992)

3. Keputusan penggunaan sistem informasi dalam menyelesaikan tugas pengguna (Davis, 1989)

4. Jumlah dari fitur-fitur sistem informasi yang digunakan (Green and Hughes, 1986)

\subsubsection{Kepuasan Pengguna (user satisfaction}

Kepuasan merupakan perbandingan antara harapan dan hasil yang diperoleh pengguna. Jika hasil yang diperoleh sama atau lebih dari harapan maka pengguna akan merasa puas (Kotler,2003).

Kepuasan dapat diukur melalui dua indikator :

1. Loyal

2. Adanya komunikasi dari mulut ke mulut yang bersifat positif

\subsubsection{Dampak Individu ( Indvidual Impact )}

Dampak Individu ( Indvidual Impact ) merupakan efek dari informasi terhadap perilaku pengguna. Dampak berhubungan erat dengan kinerja, yaitu meningkatkan kinerja individu pengguna sistem. Menurut (Mason,1978) menunjukkan urutan dampak (impact) mulai dari menerima informasi, pemahaman informasi, aplikasi dari informasi tersebut ke suatu permasalahan tertentu, dan merubah perilaku keputusan, dan dengan hasil perubahan kinerja organisasi.

Menurut (Chervany et al,1972) menggunakan pengukuran efektivitas keputusan (decision effectivenees) untuk mengukur dampak (impact) dari sistem informasi. Efektivitas keputusan (decision effectivenees) mempunyai beberapa indicator, yaitu rata-rata waktu untuk membuat suatu keputusan (average time to make a decision), keyakinan dalam pengambilan keputusan (the confidence in the decision made), dan jumlah laporan diminta (the number of reports requested). (Rivard and Huff,1984) memasukkan produktivitas pengguna meningkat (increased user productivity) untuk mengukur dampak (impact), dan (DeBrabander and Thiers, 1984) menggunakan efisiensi dari penyelesaian tugas (effiency of task accomplishment) untuk mengukur dampak (impact).

\subsubsection{Dampak organisasi (organization impact)}

Dampak organisasi (organization impact) merupakan dampak (impact) dari informasi terhadap kinerja organisasi. (Chervany et al,1972) menggunakan pengurangan biaya untuk mengukur kinerja organisasi. (Emery,1971) menggunakan pengurangan biaya-biaya operasi dari aktivitas-aktivitas di luar kegiatan sistem informasi. (Rivard and Huff,1984) menggunakan penguranganpengurangan biaya-dan keuntungan-keuntungan yang yang direalisasi dari aplikasi tertentu yang dikembangkan untuk pengguna. (Lucas,1973) dan juga (Hamilton and Chervanya,1981) menggunakan pendapatan perusahaan yang dapat ditingkatkan karena sistem informasi berbasis computer. (Chismar and Kriebel, 
1985) menggunakan peningkatan penjualan dan return on investment terhadap biaya-biaya input sistem informasi.

Beberapa pengukuran lain yang mengukur dampak (impact) organisasi adalah sebagai berikut :

1. Kecepatan analisis keputusan (speed of decision analysis) untuk mengukur kesuksesan DSS (Sanders and Courtney,1985).

2. Kerelaan untuk membayar biaya pengembangan sistem informasi untuk meningkatkan kemampuan DSS (Keen,1981).

3. Kerelaan membayar untuk informasi tertentu yang akan meningkatkan nilai keputusan (Hilton and Swieringa, 1982).

Menurut (Jenster, 1987) memasukkan pengukuran non-keuangan dari dampak (impact) organisasi seperti produktivitas (productivity), inovasi (innovation), dan kualitas produk (product quality). (Daziger, 1977) menggunakan hasil produktivitas (productivity gain) di organisasi nirlaba.

Dalam penelitiannya di University of California (Irvine and Danziger,1977) menggunakan lima pengukuran hasil produktivitas (productivity gain) yaitu pengurangan staf (staff reduction), pengurangan biaya (cost reduction), meningkatkan volume pekerjaan (increased work volume), informasi baru (new information), dan meningkatkan efektivitas dalam melayani public (increased effectiveness in serving the public).

\subsection{Structural Equation Modeling (SEM)}

Structural Equation Modeling (SEM) adalah alat analisis statistik yang semakin popular saat ini. Jika dilihat dari penyusunan model serta cara kerjanya, sebenarnya SEM adalah gabungan dari analisis factor dan regresi. Pada tahun 1950, SEM sudah mulai dikemukakan oleh para ahli statistik yang mencari metode untuk membuat model yang dapat menjelaskan hubungan di antara variabel-variabel. Persoalan timbul karena banyak variabel yang termasuk dalam variabel laten yang menimbulkan kesulitan tersendiri dalam pengukurannya.

Variabel laten adalah variabel yang tidak dapat diukur secara langsung kecuali diukur dengan satu atau lebih variabel manifes. Variabel manifes adalah variabel yang digunakan untuk menjelaskan atau mengukur sebuah variabel laten. Sebagai contoh, seseorang tidak dapat mengukur variabel laten komitmen kecuali dikembangkan sejumlah variabel yang dapat merinci elemen-elemen dari komitmen tersebut. Misal didapat empat elemen variabel manifes, lalu dikembangkan sejumlah pertanyaan atau alat ukur lain untuk mengukur masingmasing empat elemen terebut.

Proses SEM sulit dilakukan secara manual, selain karena keterbatasan 
kemampuan manusia, juga karena kompleksitas model dan alat statistik yang digunakan. Walaupun banyak ahli di pertengahan abad 20 sedah menyadari perlunya membuat model yang dapat menjelaskan banyak fenomena social atau alam dalam hubungan banyak variabel, namun mereka belum dapat menangani kompleksitas perhitungan matematisnya.

Kemajuan teknologi informasi, khususnya dalam pengembangan pembuatan software, telah mendorong munculnya software khusus untuk perhitungan alat statistik dasar dari SEM, yakni analisis faktor dan analisis regresi berganda. Saat ini banyak software yang khusus digunakan untuk analisis model SEM, seperti amos.

\section{Pembahasan}

\subsection{Model Pengembangan Kesuksesan Sistem Informasi}

Model pengembangan kesukses sistem informasi adalah modifikasi dari model Delone \& McLean dengan menghilangkan panah penggunaan terhadap kepuasan pengguna dan menambah komponenl kualitas layanan.. Menurut (McGill et all,2003) dalam penelitiaannya menunjukkan bahwa kepuasan pengguna berpengaruh terhadap penggunaan bukan sebaliknya. Apabila komponen kualitas layanan tidak diikut sertakan, maka akan terdapat kesalahan dalam pengukuran efektifitas sistem informasi.

Maka model pengembangan kesuksesan sistem informasi dapat digambarkan sebagai berikut :

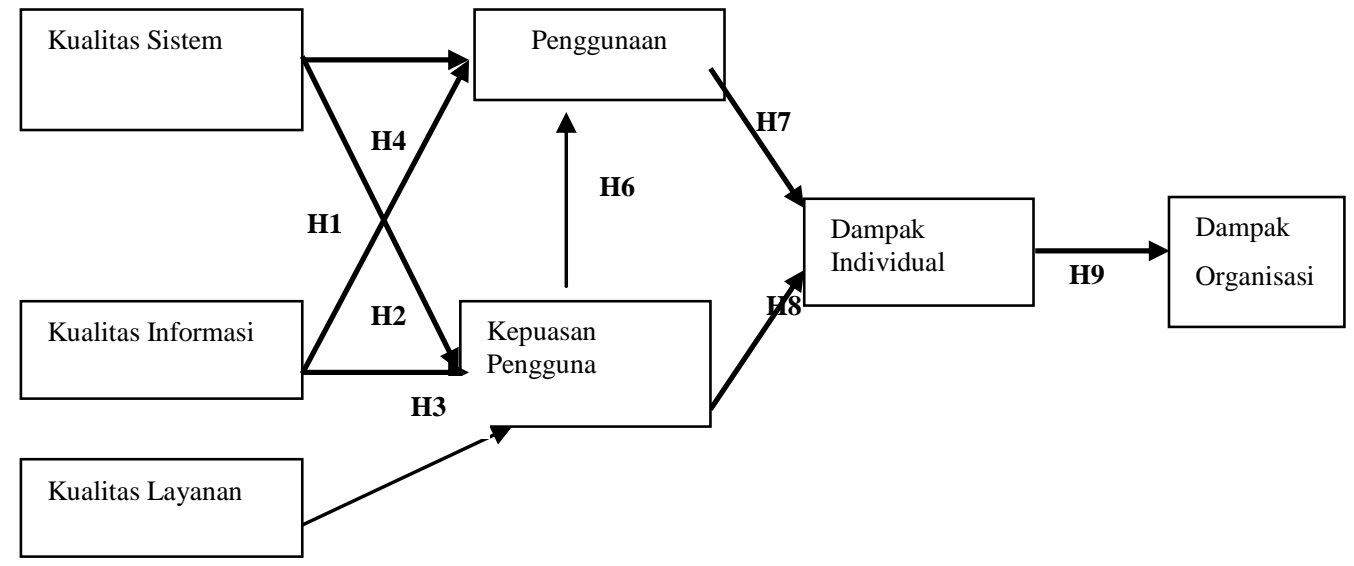

Gambar 3.1 Model pengembangan kesuksesanSistem Informasi

\subsection{Metodologi Pengukuran Kesuksesan Sistem Informasi}

Dalam mengukur kesuksesan sistem informasi diperlukan sebuah metodologi agar memiliki sistematika dan langkah-langkah yang harus dilakukan. Berikut adalah metodologi yang dipegunakan untuk mengukur kesuksesan sistem informasi : 


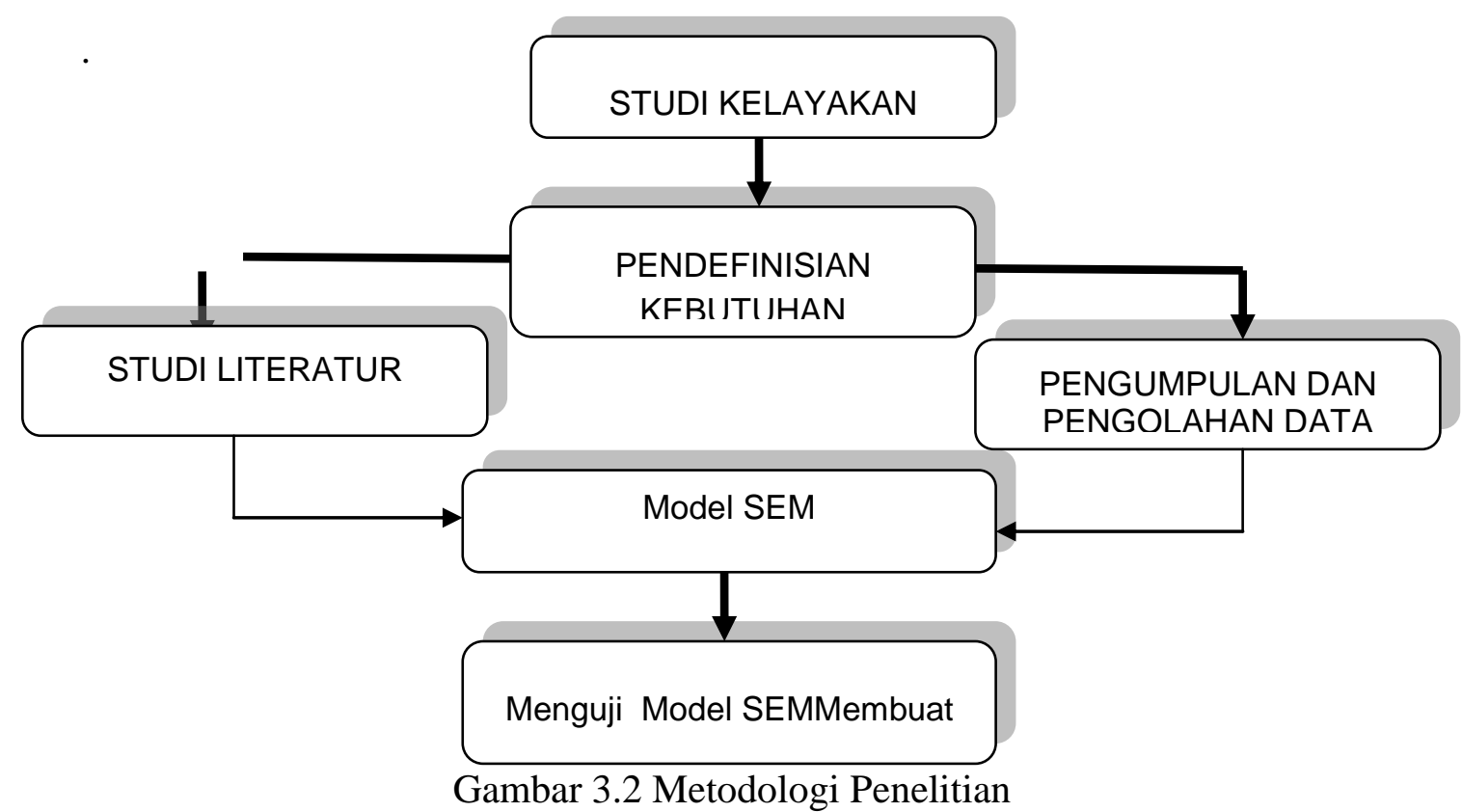

Adapun tahapan metodologi diuraikan sebagai berikut :

3.2.1. Studi Kelayakan

Tahapan ini dilakukan untuk mengetahui permasalahan yang terjadi sehingga dapat dirumuskan masalah yang diteliti dan solusi serta tujuan yang akan dicapai dalam penelitian ini.

\subsubsection{Pendefinisian Kebutuhan}

Tahapan ini dilakukan untuk untuk mengetahui sistem informasi yang sudah berjalan .

\subsubsection{Studi Literatur}

Tahapan ini dilakukan untuk mengumpulkan bahan-bahan rujukan yang berhubungan dengan permasalan kesuksesan sistem informasi.

\subsubsection{Pengumpulan dan Pengolahan Data}

Pengumpulan data dilakukan dengan questioner. Setelah hasil questioner dikumpulkan kemudian dilakukakan pengolahan data untuk mengetahui uji validitas,uji reliabilitas, uji linear, dan uji .

\subsubsection{Membuat Model SEM}

Berdasarkan faktor-faktor kesuksesan sistem informasi diperoleh variabelvariabel penelitian sebagai berikut :

Gambar 3.3. Tabel Variabel Penelitian

\begin{tabular}{|c|l|l|c|}
\hline Nomor & \multicolumn{1}{|c|}{$\begin{array}{c}\text { Variabel } \\
\text { Laten }\end{array}$} & \multicolumn{1}{|c|}{ Variabel Manifes } & Sumber \\
\hline 1 & Kualitas & 1. Reliabilitas, & Nelson et al, 2005) \\
& Sistem & 2. Fleksibilitas & \\
\hline
\end{tabular}




\begin{tabular}{|c|c|c|c|}
\hline & & $\begin{array}{ll}\text { 3. } & \text { Aksesibilitas } \\
\text { 4. } & \text { Waktu respon }\end{array}$ & \\
\hline 2 & $\begin{array}{l}\text { Kualitas } \\
\text { Informasi }\end{array}$ & $\begin{array}{l}\text { 1. Akurat } \\
\text { 2. Tepat pada waktunya } \\
\text { 3. Relevan }\end{array}$ & (Jogiyanto,2007) \\
\hline 3 & $\begin{array}{l}\text { Kualitas } \\
\text { Layanan }\end{array}$ & $\begin{array}{l}\text { 1. Reliability (keandalan) } \\
\text { 2. Responsiveness } \\
\text { (ketanggapan/kepeduli } \\
\text { an) } \\
\text { 3. Assurance (jaminan } \\
\text { kepastian) }\end{array}$ & (Parasuraman,1985) \\
\hline 4 & Penggunaan & $\begin{array}{l}\text { 1. Motivasi untuk } \\
\text { menggunakan sistem } \\
\text { 2. Frekuensi penggunaan } \\
\text { sistem }\end{array}$ & $\begin{array}{l}\text { (De Sanctis,1982) } \\
\text { (Culnan,1983) }\end{array}$ \\
\hline 5 & $\begin{array}{l}\text { Kepuasan } \\
\text { pengguna }\end{array}$ & $\begin{array}{l}\text { 1. Loyal } \\
\text { 2. Adanya komunikasi } \\
\text { dari mulut ke mulut } \\
\text { yang bersifat positif }\end{array}$ & (Kotler,2003) \\
\hline 6 & $\begin{array}{l}\text { Dampak } \\
\text { Individu }\end{array}$ & $\begin{array}{l}\text { 1. Keyakinan pengguna } \\
\text { 2. Pemahaman informasi } \\
\text { 3. Efisiensi dari } \\
\text { penyelesaian tugas }\end{array}$ & $\begin{array}{ll}\text { (Aldag } & \text { and } \\
\text { Power,1986) } & \\
\text { (Mason,1978) } & \\
\text { (DeBrabander } & \text { and } \\
\text { Thiers, 1984) } & \end{array}$ \\
\hline 7 & $\begin{array}{l}\text { Dampak } \\
\text { Organisasi }\end{array}$ & $\begin{array}{l}\text { 1. } \begin{array}{l}\text { meningkatkan } \\
\text { efektivitas } \\
\text { pelayanan }\end{array} \\
\text { 2. Informasi baru }\end{array}$ & Danziger,1987) \\
\hline
\end{tabular}

Dari model penelitian dan variabel penelitian dapat dibuat model SEM sebagai berikut 


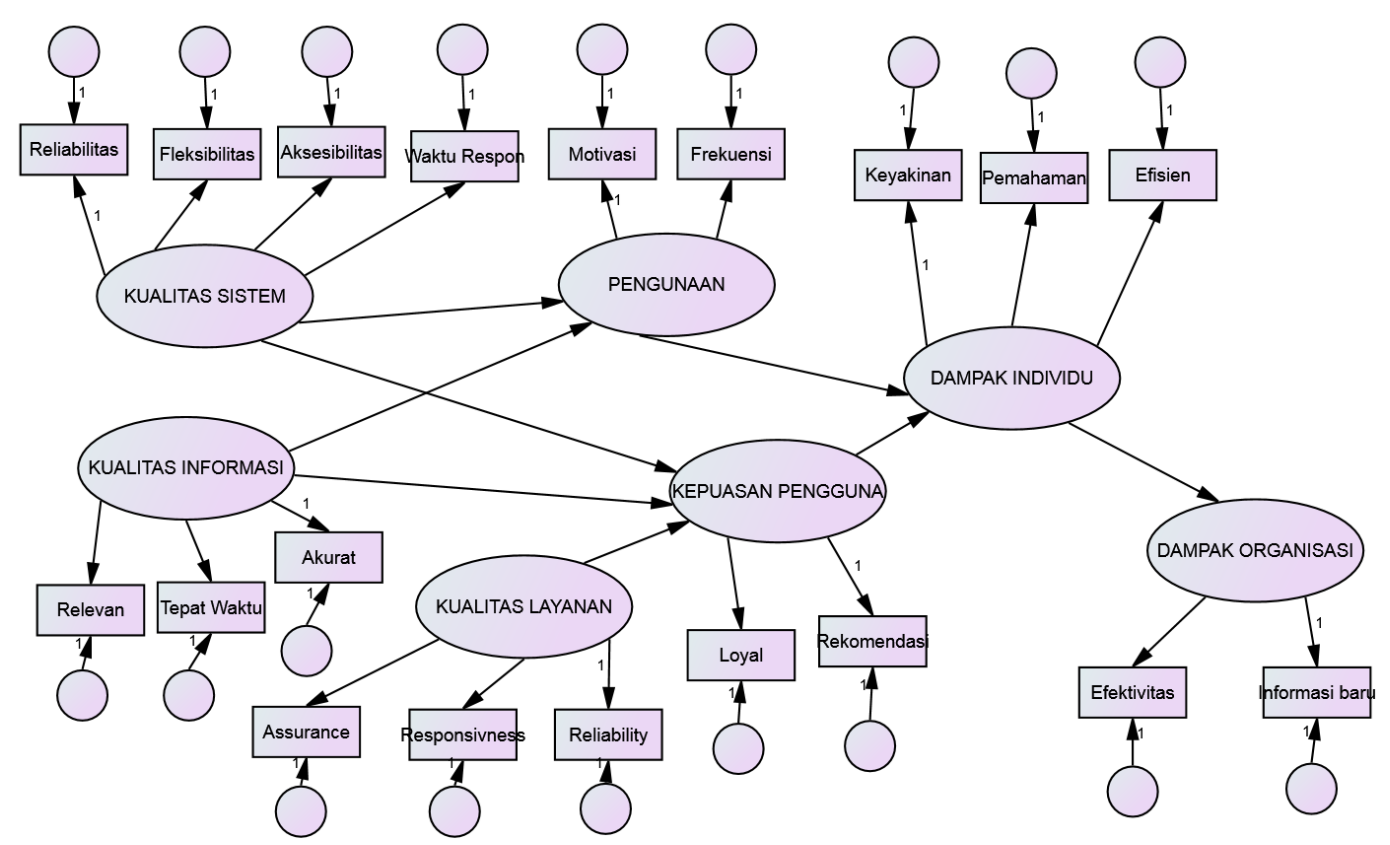

\subsubsection{Pengujian Model SEM}

Tahapan ini dilakukan untuk pengujian model SEM. Pengujian model SEM dapat dibagi menjadi dua bagian utama

1. Menguji validitas model pengukuran

2. Menguji validitas model structural

\section{Kesimpulan}

Dari kajian terhadap analisis pengukuran kesuksesan sistem informasi dapat ditarik kesimpulan :

1. Untuk menilai kesuksesan sistem informasi harus diketahui faktor-faktor penyebab kesuksesan sistem informasi

2. Dari faktor-faktor penyebab kesuksesan sistem informasi dapat dikembangkan model kesuksesan sistem informasi

3. Metodologi pengukuran kesuksesan sistem informasi dapat dijadikan pedoman untuk menilai keuksesan sistem informasi.

\section{Daftar Pustaka}

[1] Alfan Prima saputra dan Budiman Dabarsyah, Model Pengukuran Efektifitas Sistem Informasi menggunakan DeLone \& McLean, Jurnal e-Indonesia Initiatives,Vol. 2013,No.1,2013.

[2] Aldag, R.J. , and Power, D.J. , An Empirical Assessment of ComputerAssited Decision Analysis, Decision Sciences, (17:4), Fall 1986, pp. 572-588, 1986. 
[3] Culnan, M.J. , Enviromental Scanning: The Effect of Task Complexity and Source Avalaibility on Information Gathering Behavior, Decision Sciences,April 1983,pp. 194-206, 1983.

[4] DeBrabander, B. , and Thiers, G. , Successful Information Systems Development in Relation to Situational Factors Which Affect Effective Communication between MIOS-Users and EDP Specialists, Management Science (30:2), February 1984, 137-153, 1984.

[5] Delone, W.H. and McLean, ER. , "Information System Success ; The Quest For The Dependent Variable." Information System Research, March 1992.

[6] Desanctis, G. , An Examination of an Expectancy Theory Model of Decision Support Systems Use, Proceedings of the Third International Conference of Information Systems, Desember 1982,pp. 121-135,1982.

[7] Danziger,J.N., Politics,Productivity and Computers: A Contongency analysis on Local Governments,Proceedings of the Ninth International Annual Society for Management Information Systems Conference,1987, pp. 213-221

[8] Jogiyanto, Model Kesuksesan Sistem Teknologi Informasi, Andi Yogyakarta,2007.

[9] Kotler,Philip,Marketing Management (Edisi Indonesia oleh Hendra Teguh,Ronny dan Benjamin Molan),PT Indeks Jakarta,2003.

[10] Nelson, R. R., Todd, P. A., and Wixom, B. H, Antecedents of Information and System Quality: An Empirical Examination Within The Context of Data Warehousing. Management Information Systems, 21(4): 199-235,2005

[11] Parasuraman, A., Zeithaml, V. A., and Berry, L. L., A Conceptual Model Of Service Quality and Its Implication For Future Research, Journal Of Marketing, Vol. 49, pp 41- 50,1985. 